\title{
Analisis Perilaku Pengguna E-Kinerja Menggunakan Model UTAUT
}

\author{
Suparyati \\ Balai Besar Veteriner Maros \\ Jl. DR. Ratulangi, Allepolea, Lau, Kabupaten Maros, Sulawesi Selatan 90514 Indonesia \\ pariyati@gmail.com
}

\begin{abstract}
This study analyzes the behavior of E-Kinerja users at the Maros Veterinary Center using the UTAUT Model. E-Kinerja is a tool to assess the performance of employees with the status of the State Civil Apparatus (ASN) online in all work units of the Ministry of Agriculture of the Republic of Indonesia. The purpose of this study is to prove that the determinants of the use of E-performance (performance expectancy, effort expectancy, social influence, and facilitating conditions) influence the intention to behave on users (behavioral intention). The number of respondents in this study was $42 \mathrm{ASN}$ in various ranks and classes. The results of the study show that the level of ASN's acceptance of EKinerja received a positive response. This can be seen from each average value of the variables in the range of $3.54-4.34$ (on a scale of 1 to 5) on the questionnaire that has been distributed. Also, it was found that Social Influence has a positive influence on Behavioral Intention in the use of EKinerja. Whereas Habit has a positive influence on Use Behavioral in the use of E-Kinerja in BBVet Maros. As for the Performance Expectancy, Effort Expectancy, and Facilitating Conditions variables on Behavioral Intention, as well as the Facilitating Conditions and Behavioral Intention variables on Use Behavioral, no positive effect was found.
\end{abstract}

Keyword: UTAUT, Behavioural Intention, Use Behavioral, Performance Expentancy, Effort Expentancy, Social Influence, Facilitating Conditions

\begin{abstract}
ABSTRAK
Penelitian ini menganalisa perilaku pengguna E-Kinerja pada Balai Besar Veteriner Maros (BBVet Maros) menggunakan Model UTAUT. E-Kinerja merupakan tools untuk menilai kinerja pegawai yang berstatus Aparatur Sipil Negara (ASN) secara online pada semua unit kerja Kementerian Pertanian Republik Indonesia. Adapun tujuan dari penelitian ini untuk membuktikan bahwa faktorfaktor determinan pemanfaatan E-Kinerja (performance expentancy, effort expentancy, social influence, dan facilitating conditions) mempengaruhi niat berperilaku pada penggunanya (behavioural intention). Jumlah responden dalam penelitian ini sebanyak 42 ASN berbagai tingkatan pangkat dan golongan. Hasil penelitian bahwa tingkat penerimaan ASN terhadap E-Kinerja mendapat tanggapan yang positif. Hal ini dapat dilihat dari setiap nilai rata - rata variabel yang berada di rentang 3,54-4,34 (dari skala 1 sampai 5) pada kuesioner yang telah disebar. Selain itu ditemukan pula bahwa Social Influence memiliki pengaruh yang positif terhadap Behavioral Intention dalam pemanfaatan E-Kinerja. Sedangkan Habit memiliki pengaruh yang postif terhadap Use Behavioral dalam pemanfaatan E-Kinerja pada BBVet Maros. Adapun untuk variabel Performance Expentancy, Effort Expentancy, dan Facilitating Conditions terhadap Behavioral Intention, serta variabel Facilitating Conditions dan Behavioral Intention terhadap Use Behavioral, tidak ditemukan adanya pengaruh yang positif.
\end{abstract}

Kata kunci: UTAUT, Behavioural Intention, Use Behavioral, Performance Expentancy, Effort Expentancy, Social Influence, Facilitating Conditions 


\section{PENDAHULUAN}

E-Kinerja merupakan salah satu produk inovasi dari Kementerian Pertanian RI (Kementan) untuk mempermudah Aparatur Sipil Negara (ASN) dilingkup Kementan sehingga dapat mengukur kinerja masing-masing. Sistem ini diaplikasikan guna mendukung UU No. 43 Tahun 1999 pasal 12 ayat 2 yang mengamanatkan Penilaian prestasi kerja ASN bertujuan untuk menjamin objektifitas pembinaan ASN yang dilakukan berdasarkan sistem prestasi kerja \& sistem karier, yang dititikberatkan pada sistem prestasi kerja. Penilaian prestasi kerja ASN diarahkan sebagai pengendalian perilaku kerja produktif yang disyaratkan untuk mencapai hasil kerja yg disepakati dan dilakukan berdasarkan prinsip objektif, terukur, akuntabel, partisipatif, dan transparan.

E-Kinerja merupakan tools untuk menilai kinerja pegawai. Penilaian dilaksanakan oleh pejabat penilai sekali dalam sebulan. Dalam rangka program percepatan Reformasi Birokrasi, mulai tahun 2018 seluruh pegawai diwajibkan untuk mengisi Sasaran Kerja Pegawai (SKP) pada http://ekinerja.pertanian.go.id/epersonalv2. E-Kinerja merupakan perkembangan dari Daftar Penilaian Pelaksanaan Pekerjaan (DP3) yang dinilai belum mampu menyajikan penilaian pegawai secara objektif, terukur, transparan dan adil. Dengan E-Kinerja, diharapkan seluruh pegawai lebih produktif dan proaktif.

Teknologi informasi mempunyai peranan yang sangat penting dalam proses pengambilan keputusan oleh pihak manajemen yang mana informasi tersebut didapatkan melalui sistem informasi yang ada di instansi. Sistem informasi merupakan kombinasi teratur dari manusia, perangkat keras, perangkat lunak jaringan komunikasi dan sumber daya data, yang mengumpulkan, mengubah dan menyebarkan informasi dalam suatu organisasi untuk mendukung keputusan dan mengontrol organisasi [1].

UTAUT (Unified Teory of Acceptance and Use of Technology) merupakan sebagai sebuah model untuk menjelaskan perilaku pengguna terhadap teknologi informasi [2]. Model ini menunjukkan bahwa niat untuk berperilaku (behavioural intention) dan perilaku untuk menggunakan suatu teknologi (use behaviour) dipengaruhi akan kinerja (performance expectancy), harapan akan usaha (effort expectancy), pengaruh sosial (social influence), dan kondisi pendukung (facilitating condition). Faktor-faktor tersebut dimoderasi oleh faktor jenis kelamin (gender), usia (age), pengalaman (experience), dan kesukarelaan menggunakan vountariness of use)[2]. Penelitian empiris yang mengadopsi model ini sudah banyak dilakukan dan mendapatkan hasil yang beragam [3]- [18].

Pada UTAUT model, ekspektasi kinerja dan ekspektasi usaha digunakan untuk menggabungkan konstruk persepsi kegunaan dan kemudahan penggunaan dalam studi TAM asli. Meskipun model UTAUT mengandaikan bahwa upaya Konstruksi harapan dapat menjadi signifikan dalam menentukan penerimaan pengguna terhadap teknologi informasi, kekhawatiran akan kemudahan penggunaan dapat menjadi tidak signifikan jika penggunaannya diperpanjang dan berkelanjutan. Karena itu, persepsi kemudahan penggunaan dapat diharapkan lebih efisien hanya pada tahap awal penggunaan teknologi baru dan itu dapat memiliki efek positif pada manfaat yang dirasakan dari teknologi.

UTAUT mencoba menjelaskan niat untuk menggunakan, sebagai serta perilaku penggunaan selanjutnya. Teori menunjukkan bahwa empat konstruksi utama: 1. Kinerja harapan, 2. harapan usaha, 3. pengaruh sosial, dan 4. Kondisi fasilitasi adalah penentu langsung niat penggunaan dan perilaku [19]. enis kelamin, usia, pengalaman, dan kesukarelaan penggunaan akan memediasi dampak dari empat konstruksi pada niat untuk menggunakan dan perilaku penggunaan [19]. 


\section{KILAT}

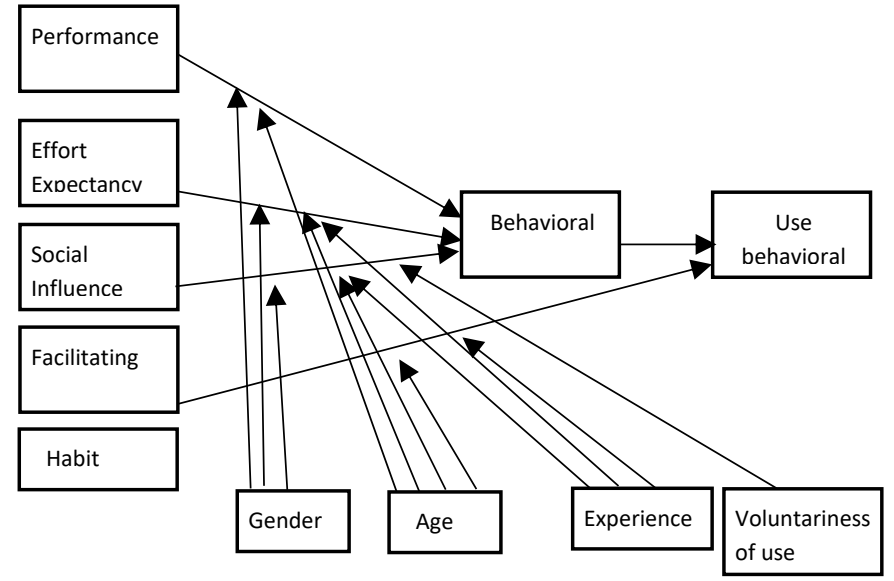

Gambar 1. Model UTAUT [19]

Penelitian dengan UTAUT memiliki tujuan untuk membantu organisasi dalam memahami cara pengguna beraksi terhadap pengenalan teknologi baru [21].

Sampai saat ini UTAUT sudah dikembangkan kembali dari konteks organisasi menjadi konteks konsumen individu yang diberi nama Model UTAUT2 di mana habit, hedonic motivation dan price value ditambahkan sebagai konstruksi baru.

\section{METODOLOGI PENELITIAN}

Metode penelitian yang digunakan dalam penelitian adalah metode kuantitatif. Data yang digunakan merupakan data primer yaitu data yang diperoleh langsung dari lapangan [22]. Pengambilan sample menggunakan Proportionate Stratified Random Sampling. Jawaban responden dalam penelitian ini akan diukur dengan skala likert dengan interval: $1=$ Sangat Tidak Setuju; $2=$ Tidak Setuju; 3 = Netral; 4 = Setuju; 5 = Sangat Setuju. Penelitian ini menggunakan model UTAUT yang lebih sederhana seperti gambar 2 .

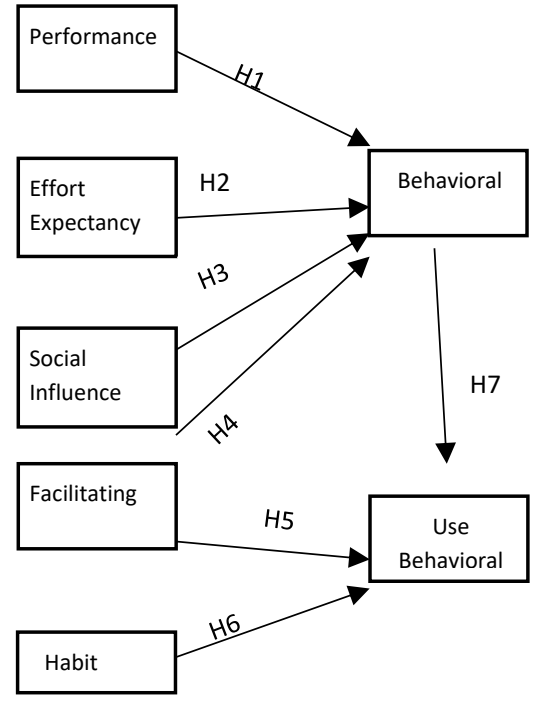

Gambar 2. Model Usulan UTAUT

Data dalam penelitian diperoleh dengan menyebarkan kuesioner pada pengguna E-Kinerja pada BBVet Maros. Jumlah kuesioner yang disebar sebanyak 67 kuesioner, jumlah kuesioner kembali 
sebanyak 48 kuesioner (respon rate 71,64\%). Kuesioner yang lengkap dan dapat diproses sebanyak 42 kuesioner (useable rate $87,5 \%$ ).

Hipotesis yang akan diuji yang dapat dilihat pada Gambar 2 yang meliputi:

H1: Ekspektasi kinerja (Performance Expectancy) mempunyai pengaruh positif terhadap minat dalam menggunakan E-Kinerja (Behavioral Intention to Use System).

H2: Ekspektasi usaha (Effort Expectancy) mempunyai pengaruh positif terhadap minat pemanfaatan dan penggunaan E-Kinerja (Behavioral Intention to Use System).

H3: Faktor sosial (Social Influence) mempunyai pengaruh positif terhadap minat pemanfaatan dan penggunaan E-Kinerja (Behavioral Intention to Use System).

H4: Kondisi - kondisi Pemfasilitasi (Facilitating Conditions) mempunyai pengaruh positif terhadap minat pemanfaatan dan penggunaan E-Kinerja (Behavioral Intention to Use System).

H5: Kondisi - kondisi Pemfasilitasi (Facilitating Conditions) mempunyai pengaruh positif terhadap perilaku penggunaan E-Kinerja (Use Behavioral).

H6: Faktor Kebiasaan (Habit) mempunyai pengaruh positif terhadap perilaku penggunaan E-Kinerja (Use Behavioral).

H7: Minat pemanfaatan dan penggunaan E-Kinerja (Behavioral Intention to Use System) mempunyai pengaruh positif terhadap perilaku penggunaan E-Kinerja (Use Behavioral).

\section{HASIL DAN PEMBAHASAN}

Analisis data yang dilakukan melalui dua tahap, yaitu uji kualitas data berupa uji validitas dan uji reliabilitas. Nilai $\mathrm{r}$ table signifikan $5 \%$. $\mathrm{df}=(\mathrm{N}-2)$. $\mathrm{df}=42-2=40$. Maka $\mathrm{r}$ table $=0.3044$. Ketentuan Validitas instrument apabila $r$ hitung lebih besar dengan $r$ tabel. Dasar pengambilan keputusan, $r$ hitung $>r$ tabel maka variabel valid. $r$ hitung $<r$ tabel maka variabel tidak valid[23].

Tabel 1. Uji Validitas Performance Expectancy

\begin{tabular}{|l|c|l|}
\hline Item & Koefisien Korelasi dengan Total Nilai & Keterangan \\
\hline PE1 & $.721^{* *}$ & Valid \\
\hline PE2 & $.916^{* *}$ & Valid \\
\hline PE3 & $.815^{* *}$ & Valid \\
\hline PE4 & $.739^{* *}$ & Valid \\
\hline PE5 & $.875^{* *}$ & Valid \\
\hline PE6 & $.899^{* *}$ & Valid \\
\hline
\end{tabular}

Tabel 2. Uji Validitas Effort Expectancy

\begin{tabular}{|l|c|l|}
\hline Item & Koefisien Korelasi dengan Total Nilai & Keterangan \\
\hline EE1 & $.843^{* *}$ & Valid \\
\hline EE2 & $.875^{* *}$ & Valid \\
\hline EE3 & $.664^{* *}$ & Valid \\
\hline EE4 & $.789^{* *}$ & Valid \\
\hline
\end{tabular}




\section{KILAT}

Vol. 8, No. 2, Oktober 2019, P-ISSN 2089-1245, E-ISSN 2655-4925

Tabel 3. Uji Validitas Social Influence

\begin{tabular}{|l|c|l|}
\hline Item & Koefisien Korelasi dengan Total Nilai & Keterangan \\
\hline SI1 & $.878^{* *}$ & Valid \\
\hline SI2 & $.790^{* *}$ & Valid \\
\hline SI3 & $.839^{* *}$ & Valid \\
\hline SI4 & $.856^{* *}$ & Valid \\
\hline
\end{tabular}

Tabel 4. Uji Validitas Facilitating Conditions

\begin{tabular}{|l|c|l|}
\hline Item & Koefisien Korelasi dengan Total Nilai & Keterangan \\
\hline FC1 & $.977^{* *}$ & Valid \\
\hline FC2 & $.976^{* *}$ & Valid \\
\hline
\end{tabular}

Tabel 5. Uji Validitas Habit

\begin{tabular}{|l|c|l|}
\hline Item & Koefisien Korelasi dengan Total Nilai & Keterangan \\
\hline H1 & $.872^{* *}$ & Valid \\
\hline H2 & $.876^{* *}$ & Valid \\
\hline
\end{tabular}

Tabel 6. Uji Validitas Behavioral Intention to Use System

\begin{tabular}{|l|c|l|}
\hline Item & Koefisien Korelasi dengan Total Nilai & Keterangan \\
\hline BI1 & $.946^{* *}$ & Valid \\
\hline BI2 & $.936^{* *}$ & Valid \\
\hline
\end{tabular}

Tabel 7. Uji Validitas Use Behavioral

\begin{tabular}{|l|c|l|}
\hline Item & Koefisien Korelasi dengan Total Nilai & Keterangan \\
\hline UB1 & $.832^{* *}$ & Valid \\
\hline UB2 & $.790^{* *}$ & Valid \\
\hline
\end{tabular}

Berdasarkan hasil data dari kuesioner yang telah diolah pada tabel 1 hingga tabel 7 diketahui bahwa semua indikator bernilai valid. Hal ini dapat dibuktikan dari semua nilai kolerasi skor item indikator memiliki nilai lebih besar dari r-tabel. Sehingga pernyataan-pernyataan yang terdapat pada kuisioner dianggap valid.

Setelah pengujian validitas, maka tahap selanjutnya adalah pengujian reliabilitas dengan menggunakan cronbach alpha, dengan standar 0,6. Apabila nilai cronbach alpha diatas p,6 maka pernyataan dalam kuesioner dinyatakan reliabel. Untuk uji hipotesis digunakan regresi berganda. Hasil Uji Reliabilitas disajikan dalam tabel 8 berikut ini:

Tabel 8. Uji Reliabilitas

\begin{tabular}{|l|c|c|}
\hline \multicolumn{1}{|c|}{ Butir Pertanyaan } & Nilai Cronbach Alpha & Keterangan \\
\hline $\begin{array}{l}\text { Performance } \\
\text { Expectancy }(\mathrm{X} 1)\end{array}$ & .801 & Reliabel \\
\hline $\begin{array}{l}\text { Effort Expectancy } \\
\text { (X2) }\end{array}$ & .813 & Reliabel \\
\hline Social Influence $(\mathrm{X} 3)$ & .827 & Reliabel \\
\hline $\begin{array}{l}\text { Facilitating } \\
\text { Conditions }(\mathrm{X} 4)\end{array}$ & .928 & Reliabel \\
\hline Habit $(\mathrm{X} 5)$ & .879 & Reliabel \\
\hline
\end{tabular}




\begin{tabular}{|l|c|c|}
\hline $\begin{array}{l}\text { Behavioral Intention } \\
\text { to Use System }(\mathrm{Y} 1)\end{array}$ & .913 & Reliabel \\
\hline Use Behavioral $(\mathrm{Y} 2)$ & .840 & Reliabel \\
\hline
\end{tabular}

Berdasarkan hasil uji reliabilitas yang ada di tabel 8, maka dapat dikatakan bahwa data dalam penelitian ini semuanya reliable karena nilai cronbach alpha diatas 0,6.

Analisis yang digunakan dalam penelitian ini adalah analisis jalur (Path Analysis). Jalur-jalur menurut hipotesis yang telah dirumuskan adalah sebagai berikut:

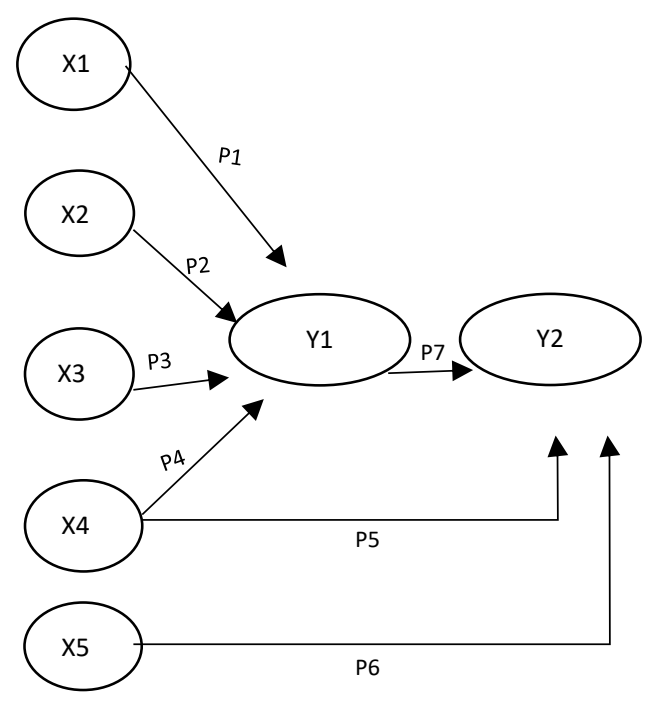

Gambar 3. Model Analisis Jalur

Persamaan untuk model hipotesis analisis jalur adalah sebagai berikut:

$\mathrm{Y} 1=\mathrm{P} 1 \mathrm{X} 1+\mathrm{P} 2 \mathrm{X} 2+\mathrm{P} 3 \mathrm{X} 3+\mathrm{P} 4 \mathrm{X} 4+\mathrm{e}_{1}$

$\mathrm{Y} 2=\mathrm{P} 5 \mathrm{X} 4+\mathrm{P} 6 \mathrm{X} 5+\mathrm{P} 7 \mathrm{Y} 1+\mathrm{e}_{2}$

Tahap selanjutnya adalah meregresikan dan menghitung koefisien jalur model I dan model II.

Tabel 9. Model Summary 1

\begin{tabular}{lc|c|c|c} 
Model & $\mathrm{R}$ & R Square & Adjusted R Square & Std. Error of the Estimate \\
\hline 1 & $\begin{array}{c}.938 \\
\mathrm{a}\end{array}$ & .879 & .866 & .35312 \\
\hline
\end{tabular}

a. Predictors: (Constant), FC, EE, SI, PE 
Tabel 10. Coefficients Model 1

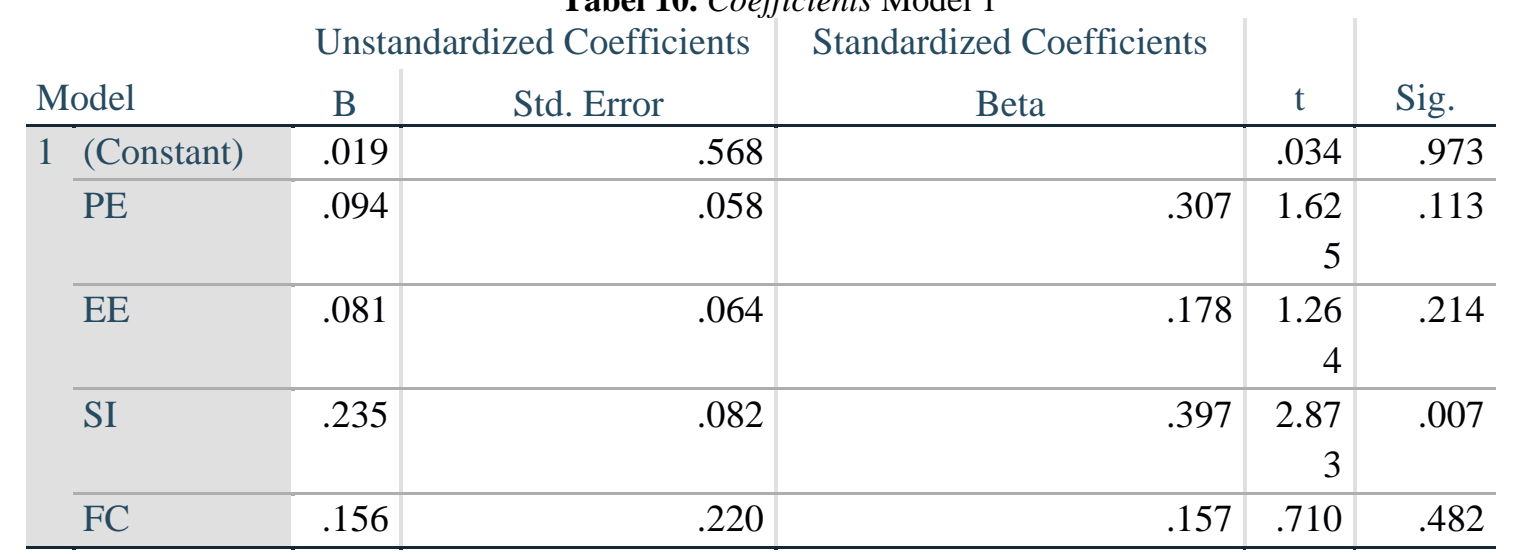

a. Dependent Variable: BI

Mengacu pada Output Regresi Model 1 pada bagian Tabel Coefficients dapat dilihat bahwa nilai signifikansi dari ke empat variabel yang diuji, hanya variabel Social Influence (X3) saja yang berpengaruh signifikan terhadap Behavioral Intention to Use System (Y1) dengan nilai sig dibawah

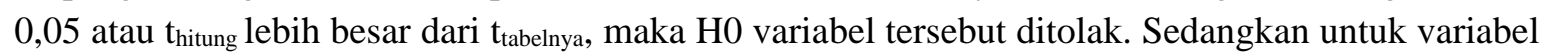
PE (X1), EE (X2) dan FC (X4) dilihat dari nilai sig yang lebih besar dari nilai probabilitas 0,05 atau

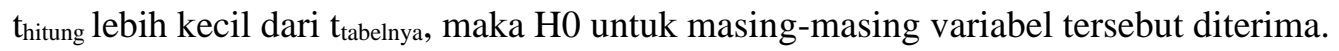

Besarnya nilai R Square 0,866 hal ini menunjukan bahwa kontribusi pengaruh PE (X1), EE (X2), SI (X3), FC (X4) terhadap BI (Y1) adalah sebesar 86,6\% sedangkan sisanya 13,4\% merupakan kontribusi variabel lain yang tidak dimasukkan dalam penelitian. Nilai e1 didapatkan dengan rumus $\mathrm{e} 1=\sqrt{ }(1-0,866)=0,366$. Berdasarkan uraian di atas, maka diperoleh diagam jalur model struktur 1 sebagai berikut:

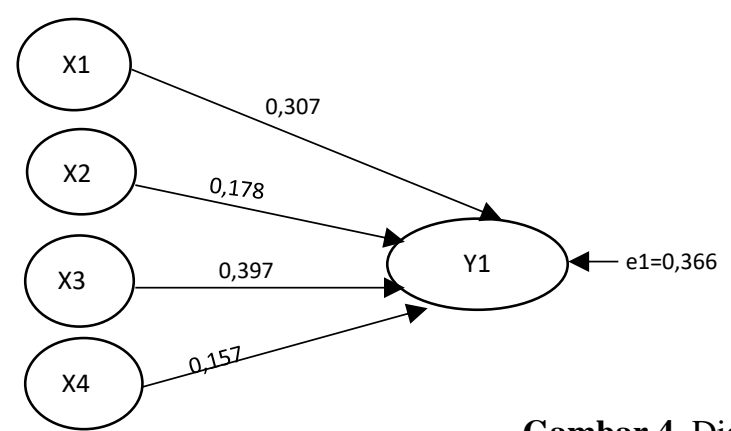

Gambar 4. Diagram Jalur Model Struktur 1

Berdasarkan gambar 4, maka substrutural yang terbentuk sebagai berikut:

$$
\begin{aligned}
\mathrm{Y} 1= & \mathrm{P} 1 \mathrm{X} 1+\mathrm{P} 2 \mathrm{X} 2+\mathrm{P} 3 \mathrm{X} 3+\mathrm{P} 4 \mathrm{X} 4+\mathrm{e}_{1} \\
& 0,307 \mathrm{X} 1+0,178 \mathrm{X} 2+0,397 \mathrm{X} 3+0,157 \mathrm{X} 4+0,366
\end{aligned}
$$

Berdasarkan model pada substruktural 1 pada analisis jalur, pengaruh yang dimiliki faktor X1, $\mathrm{X} 2, \mathrm{X} 3, \mathrm{X} 4$ terhadap Y1 hanya terdapat pengaruh langsung. 
Tabel 11. Pengaruh Langsung PE, EE, SI, FC terhadap BI

\begin{tabular}{|l|l|l|l|}
\hline \multicolumn{2}{|c|}{ Pengaruh Langsung } & \multicolumn{1}{c|}{ Perhitungan } & Besarnya Kontribusi \\
\hline X1 Langsung & $(\mathrm{P} 1 \mathrm{X} 1)^{2}$ & $(0,307)^{2}$ & 0,094 \\
\hline X2 Langsung & $(\mathrm{P} 2 \mathrm{X} 2)^{2}$ & $(0,178)^{2}$ & 0,032 \\
\hline $\mathrm{X} 3$ Langsung & $(\mathrm{P} 3 \mathrm{X} 3)^{2}$ & $(0,397)^{2}$ & 0,158 \\
\hline $\mathrm{X} 4$ Langsung & $(\mathrm{P} 4 \mathrm{X} 4)^{2}$ & $(0,157)^{2}$ & 0,025 \\
\hline \multicolumn{2}{|l}{ Total Pengaruh X1, X2, X3, X4 terhadap Y1 } & 0,309 \\
\hline
\end{tabular}

Sumber: Hasil Olah Peneliti (2019).

Berdasarkan Tabel 11, dapat dilihat bahwa Pengaruh faktor Performance Expectancy (X1), Effort Expectancy (X2), Social Influence (X3), Facilitating Conditions (X4) terhadap Behavioral Intention to Use System (Y1) sebesar 0,309 atau 30,9\% sedangkan sisanya 69,1\% dipengaruhi oleh faktor-faktor lain. Faktor UTAUT yang paling mempengaruhi Behavioral Intention to Use System adalah Social Influence dan yang paling kecil pengaruhnya adalah faktor Effort Expectancy. Hal ini dapat diartikan bahwa dalam penelitian ini, Social Influence mempengaruhi Behavioral Intention to Use System dalam penggunaan aplikasi E-Kinerja, sedangkan Effort Expectancy kurang berkontribusi terhadap Behavioral Intention to Use System dalam penggunaan E-Kinerja.

Tabel 12. Model Summary 2

\begin{tabular}{rr|r|r|r} 
Model & $\mathrm{R}$ & $\mathrm{R}$ Square & Adjusted R Square & Std. Error of the Estimate \\
\hline 1 & .868 & .753 & .734 & .43376 \\
& $\mathrm{a}$ & & & \\
\hline
\end{tabular}

a. Predictors: (Constant), BI, H, FC

Tabel 13. Coefficients Model 2

Unstandardized

Coefficients

Std Coefficients

\begin{tabular}{|c|c|c|c|c|c|}
\hline Model & B & Std. Error & Beta & $\mathrm{t}$ & Sig. \\
\hline 1 (Constant) & 1.184 & .730 & & $\begin{array}{r}1.62 \\
2\end{array}$ & .113 \\
\hline $\mathrm{FC}$ & .091 & .179 & .104 & .505 & .616 \\
\hline $\mathrm{H}$ & .714 & .162 & .714 & $\begin{array}{r}4.42 \\
0\end{array}$ & .000 \\
\hline BI & .063 & .184 & .072 & .341 & .735 \\
\hline
\end{tabular}

a. Dependent Variable: UB

Mengacu pada Output Regresi Model 2 pada bagian Tabel Coefficients dapat dilihat bahwa nilai signifikansi dari ke tiga variabel yang diuji, hanya variabel Habit (X5) saja yang berpengaruh signifikan terhadap Use Behavioral (Y2) dengan nilai sig dibawah 0,05 atau thitung lebih besar dari $\mathrm{t}_{\text {tabelnya, }}$ maka $\mathrm{H} 0$ variabel tersebut ditolak. Sedangkan untuk variabel FC (X4) dan BI (Y1) jika dilihat dari nilai sig yang lebih besar dari nilai probabilitas 0,05 atau $t_{\text {hitung }}$ lebih kecil dari $t_{\text {tabelnya }}$, maka $\mathrm{H} 0$ untuk masing-masing variabel tersebut diterima.

Besarnya nilai R Square 0,753 hal ini menunjukan bahwa kontribusi pengaruh FC (X4), H (X5), SI (X3), BI (X6) terhadap UB (Y2) adalah sebesar 75,3\% sedangkan sisanya 24,7\% merupakan kontribusi variabel lain yang tidak dimasukkan dalam penelitian. Nilai e1 didapatkan dengan rumus 


\section{KILAT}

Vol. 8, No. 2, Oktober 2019, P-ISSN 2089-1245, E-ISSN 2655-4925

e1 $=\sqrt{ }(1-0,734)=0,516$. Berdasarkan uraian di atas, maka diperoleh diagam jalur model struktur 2 sebagai berikut:

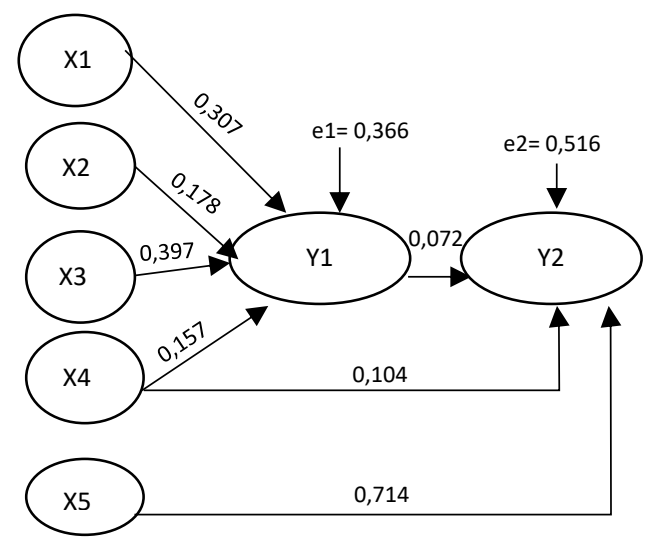

Gambar 5. Diagram Jalur Model Struktur 2

Berdasarkan model pada Gambar 5 tentang substruktural 2 pada analisis jalur, pengaruh yang dimiliki faktor X1, X2, X3, X4 terhadap Y2 terdapat pengaruh tidak langsung sedangkan factor X4, X5, Y1 terhadap Y2 memiliki pengaruh langsung.

Tabel 14. Total Pengaruh Faktor PE, EE, SI, FC, H, BI terhadap Use Behavioral (UB)

\begin{tabular}{|c|c|c|c|c|}
\hline Var. & Pengaruh & Bobot & Jumlah & Total \\
\hline \multirow[t]{2}{*}{$\mathrm{X} 1$} & Langsung & 0,00 & \multirow[t]{2}{*}{$(0,022)^{2}$} & \multirow[t]{2}{*}{0,0004} \\
\hline & Tidak Langsung & $\begin{array}{l}0,307 * 0,072 \\
=0,022\end{array}$ & & \\
\hline \multirow[t]{2}{*}{$\mathrm{X} 2$} & Langsung & 0,00 & \multirow[t]{2}{*}{$(0,013)^{2}$} & \multirow[t]{2}{*}{0,0002} \\
\hline & Tidak Langsung & $\begin{array}{l}0,178 * 0,072 \\
=0,013\end{array}$ & & \\
\hline \multirow[t]{2}{*}{ X3 } & Langsung & 0,00 & \multirow[t]{2}{*}{$(0,029)^{2}$} & \multirow[t]{2}{*}{0,0008} \\
\hline & Tidak Langsung & $\begin{array}{l}0,397 * 0,072 \\
=0,029\end{array}$ & & \\
\hline \multirow[t]{2}{*}{$\mathrm{X} 4$} & Langsung & 0,104 & \multirow[t]{2}{*}{$(0,011)^{2}$} & \multirow[t]{2}{*}{0,0001} \\
\hline & Tidak Langsung & $\begin{array}{l}0,157 * 0,072 \\
=0,011\end{array}$ & & \\
\hline X5 & Langsung & 0,714 & $(0,714)^{2}$ & 0,5098 \\
\hline Y1 & Langsung & 0,072 & $(0,072)^{2}$ & 0,0051 \\
\hline
\end{tabular}

Sumber: Hasil Olah Peneliti (2019).

Nilai total dari koefisien determinasi $\left(\mathrm{R}^{2}\right)$ menunjukkan bahwa dengan menggunakan model analisis jalur, variabel exogenous yaitu Performance Expectancy (X1), Effort Expectancy (X2), Social Influence (X3), Facilitating Conditions (X4), Habit (X5), memiliki pengaruh terhadap perubahan variabel endogenous Use Behavioral (Y2) dengan Behavioral Intention to Use System (Y1) sebagai variabel perantara sebanyak 0,5164 atau 51,64\%.

Faktor Habit memiliki pengaruh langsung paling besar dibandingkan dengan faktor UTAUT lainnya sekaligus menjadi faktor yang paling mempengaruhi Use Behavioral secara keseluruhan dalam menggunakan aplikasi E-Kinerja. Sedangkan ketika melalui Behavioral Intention to Use 
System, faktor Social Influence mempunyai pengaruh tidak langsung yang paling besar dibandingkan dengan faktor lainnya.

\section{KESIMPULAN}

Berdasarkan hasil penelitian maka dapat disimpulkan bahwa: (1) Ekspektasi kinerja (Performance Expectancy) tidak berpengaruh terhadap minat dalam menggunakan E-Kinerja (Behavioral Intention to Use System); (2) Ekspektasi usaha (Effort Expectancy) tidak berpengaruh terhadap minat pemanfaatan dan penggunaan E-Kinerja (Behavioral Intention to Use System); (3) Faktor sosial (Social Influence) mempunyai pengaruh positif terhadap minat pemanfaatan dan penggunaan E-Kinerja (Behavioral Intention to Use System); (4) Kondisi-kondisi Pemfasilitasi (Facilitating Conditions) tidak berpengaruh terhadap minat pemanfaatan dan penggunaan E-Kinerja (Behavioral Intention to Use System); (5) Kondisi-kondisi Pemfasilitasi (Facilitating Conditions) tidak berpengaruh terhadap perilaku penggunaan E-Kinerja (Use Behavioral); (6) Faktor Kebiasaan (Habit) mempunyai pengaruh positif terhadap perilaku penggunaan E-Kinerja (Use Behavioral); (7) Minat pemanfaatan dan penggunaan E-Kinerja (Behavioral Intention to Use System) tidak berpengaruh terhadap perilaku penggunaan E-Kinerja (Use Behavioral).

\section{DAFTAR PUSTAKA}

[1] O’brien, J. Pengantar Sistem Informasi: Perspektif Bisnis dan Managerial, Edisi 12, Salemba, 2006.

[2] Venkatesh, V., Morris, M., Davis, G., \& Davis, F. (2003). User Acceptance Of Information Technology: Toward A Unified View. MIS Quarterly, 27(3), 425-478.

[3] Im, IL; Hong, Seongtae; Kang, Myung Soo. An International Comparison Of Technology Adoption: Testing The UTAUT Model. Information \& Management, 2011, 48.1: 1-8.

[4] Carlsson, Christer, et al. Adoption Of Mobile Devices/Services-Searching For Answers With The UTAUT. In: Proceedings Of The 39th Annual Hawaii International Conference On System Sciences (HICSS'06). IEEE, 2006. p. 132a-132a.

[5] Yu, Chian-Son. Factors Affecting Individuals To Adopt Mobile Banking: Empirical Evidence From The UTAUT Model. Journal Of Electronic Commerce Research, 2012, 13.2: 104.

[6] Alawadhi, Suha; Morris, Anne. The Use Of The UTAUT Model In The Adoption Of EGovernment Services In Kuwait. In: Proceedings Of The 41st Annual Hawaii International Conference On System Sciences (HICSS 2008). Ieee, 2008. p. 219-219.

[7] Kijsanayotin, Boonchai; Pannarunothai, Supasit; Speedie, Stuart M. Factors Influencing Health Information Technology Adoption In Thailand's Community Health Centers: Applying the UTAUT model. International Journal Of Medical Informatics, 2009, 78.6: 404-416.

[8] Anderson, John E.; Schwager, Paul H. SME Adoption Of Wireless LAN Technology: Applying The UTAUT Model. In: Proceedings Of The 7th Annual Conference Of The Southern Association For Information Systems. 2004. p. 39-43.

[9] Putri, Aulia Maharani; Amelia, Tan; Santoso, Rudi. Pola Penerimaan Mahasiswa Terhadap Presensi RFID STIKOM Surabaya Menggunakan UTAUT 2 Models. Jurnal JSIKA, 2018, 6.3: 49-57.

[10] Nguyen, Lemai, et al. Investigating Acceptance Of Nursing Information Systems Through UTAUT lens. In: Nursing Education, Administration, and Informatics: Breakthroughs in Research and Practice. IGI Global, 2018. p. 484-503. 


\section{KILAT}

Vol. 8, No. 2, Oktober 2019, P-ISSN 2089-1245, E-ISSN 2655-4925

[11] Al-Saedi, Karrar, et al. Mobile Payment Adoption: A Systematic Review of the UTAUT Model. In: International Conference on Fourth Industrial Revolution. 2019.

[12] Raza, Syed Ali; Shah, Nida; Ali, Muhammad. Acceptance Of Mobile Banking In Islamic Banks: Evidence From Modified UTAUT Model. Journal of Islamic Marketing, 2019, 10.1: 357-376.

[13] Alshehri, Ahmed; Rutter, M. J.; Smith, Sally. An Implementation of the UTAUT Model for Understanding Students' Perceptions of Learning Management Systems: A Study Within Tertiary Institutions in Saudi Arabia. International Journal of Distance Education Technologies (IJDET), 2019, 17.3: 1-24.

[14] Lawson-Body, Assion, et al. Students' Acceptance of E-books: An Application Of UTAUT. Journal of Computer Information Systems, 2018, 1-12.

[15] Chauhan, Sumedha; Jaiswal, Mahadeo; Kar, Arpan Kumar. The Acceptance Of Electronic Voting Machines In India: a UTAUT approach. Electronic Government, an International Journal, 2018, 14.3: 255-275.

[16] Raman, Arumugam; Rathakrishnan, Mohan. Frog VLE: Teachers' Technology Acceptance Using UTAUT Model. International Journal of Mechanical Engineering and Technology (IJMET), 2018, 9.3: 529-538.

[17] Kropf, Dorothy Cortez. Applying UTAUT to Determine Intent to Use Cloud Computing in K12 Classrooms. 2018.

[18] Barrane, Fatima Zahra; Karuranga, Gahima Egide; Poulin, Diane. Technology Adoption and Diffusion: A New Application of the UTAUT Model. International Journal of Innovation and Technology Management, 2018, 15.06: 1950004.

[19] Venkatesh, V, Morris, M.G, Davis, G.B., dan Davis, F.D., 2003 "User Acceptance of Information Technology: Toward A Unified View”, MIS Quartely (27 : 3), pp. 425-478.

[20] Marchewka, Jack T., and Kurt Kostiwa. "An Application Of The UTAUT Model For Understanding Student Perceptions Using Course Management Software." Communications of the IIMA 7.2 (2007): 10.

[21] Prasetyo, Hari Basuki., Dian Anubhakti, 2011, Kajian Penerimaan Sistem E-Learning Dengan Menggunakan Pendekatan UTAUT Studi kasus Fakultas Teknologi Informasi Universitas Budi Luhur, Jurnal BIT Vol. 8, No. 2. hal. 45-47.

[22] M.I. Hasan, Pokok-Pokok Materi Metodologi Penelitian dan Aplikasinya, Ghalia Indonesia, Jakarta, 2002.

[23] Robert Ho, Handbook of Univariate and Multivariate Data Analysis and Interpretation with SPSS (Boca Raton: Chapman \& Hall/CRC, 2006) p. 184. 